\title{
PENGARUH PENDEKATAN PROBLEM POSING TERHADAP HASIL BELAJAR MATEMATIKA SISWA
}

\author{
S M Rahayu ${ }^{1, a}$, O Liyana ${ }^{2, b}$, E N Anggraini ${ }^{1, c}$ \\ ${ }^{1}$ Jurusan Pascasarjana Pendidikan Matematika, Universitas Muhammadiyah \\ Surakarta, \\ Jl. Ahmad Yani Pabelan Kartas Jawa Tengah \\ ${ }^{2}$ STKIP PGRI Bandar Lampung \\ Jl. Khairul Anwar No 79 Bandar Lampung \\ e-mail: asurimargi17@gmail.com, ${ }^{b}$ omiliyana1091@gmail.com, \\ ceka.anggraini1708@gmail.com
}

\begin{abstract}
The research used is experimental research. The population in this study were all students of class X SMA Al Azhar 3 Bandar Lampung. The population is spread in 8 classes. Two classes were sampled, namely class $X 3$ as the experimental class and class $\mathrm{X} 1$ as the control class. Sampling technique using the Cluster Rundom Samplin Technique. Data analysis used statistical formulas. The purpose of this study was to determine the effect of the problem approach on students' mathematics learning outcomes. Based on the research results obtained $t_{\text {hit }}=3,96$ and the total distribution at the significant level $5 \%$ is known $t_{\left(1-\frac{1}{3} \text { a }\right)(80)}=1,99$ while the significant level $1 \%$ is known. $t_{\left(1-\frac{1}{2} \sim c\right)(80)}=2,65$ Thus, it appears that both at the level $5 \%$ and it is $1 \%$ not in the area $t_{\text {hit }}$ of acceptance, so that there is "The Effect of the Application of the Problem Posing Approach on Students' Mathematics Learning Outcomes"
\end{abstract}

Keywords : Problem Possing, Student Learning Outcomes

\begin{abstract}
Abstrak
Penelitian yang digunakan adalah penelitian eksperimen. Populasi dalam Penelitian ini adalah seluruh siswa kelas X SMA Al Azhar 3 Bandar Lampung. Populasi tersebar dalam 8 Kelas. Dua Kelas dijadikan sampel yaitu kelas X 3 sebagai kelas eksperimen dan kelas X 1 sebagai kelas control. Teknik Pengambilan sampel menggunakan Teknik Cluster Rundom Samplin. Analisis data menggunakan rumus statistik.Tujuan Penelitian ini untuk mengtahui Pengaruh Pendekatan Problem Posing terhadap hasil belajar matematika siswa. Berdasarkan hasil penelitian yang didapat $t_{\text {hit }}=3,96$ dan dari total
\end{abstract}




\section{Hipotenusa}

Journal of Research Mathematics Education VOL.3 NO.2 2020

distribusi $t$ pada taraf signifikan $5 \%$ diketahui $t_{\left(1-\frac{1}{2}, a\right)(80)}=1,99$ sedangkan taraf signifikan $1 \%$ diketahui $t_{\left(1-\frac{1}{2} \approx \times\right)(80)}=2,65$. Dengan demikian, terlihat bahwa baik pada taraf $5 \%$ maupun $1 \%$ ternyata $t_{\text {hit }}$ tidak berada dalam daerah penerimaan $H_{0}$, sehingga ada "Pengaruh Penerapan Pendekatan Problem Posing Terhadap Hasil Belajar Matematika Siswa"

Kata kunci : Problem Posing, Hasil Belajar Matematika

\section{PENDAHULUAN}

Matematika merupakan bagian dari ilmu pengetahuan yang sangat penting dalam pendidikan. Hal ini dipahami karena matematika memiliki peran yang sangat penting dalam perkembangan ilmu pengetahuan dan teknologi[1], keadaan ini menuntut semua siswa untuk mampu menguasai matematika dengan baik. Kenyataan bahwa siswa masih mengalami kesulitan dalam belajar. kesulitan belajar matematika bukan semata-mata karena materi pelajaran matematika, Kesulitan siswa dalam pemahaman konsep, pemecahan masalah, penalaran matematyika koneksi matematika, komunikasi matematis [2] tetapi juga disebabkan kemampuan guru dalam mengelola pembelajaran matematika yang kurang efektif. Metode pembelajaran yang masih berpusat kepada guru serta anggapa siswa bahwa matematika pembelajaran yg sulit yang membuat siswa cenderung pasif serta kurang berkembang salah satunya dapat disebabkan oleh kurangnya penggunaan fasilitas dalam proses belajar mengajar [1].Rendahnya hasil belajar siswa berdasarkan hasil wawancara terhadap guru SMA Al Azhar 3 Bandar Lampung, bahwa didaptkan kesulitan yang dialami siswa antara lain : (1) masih banyak siswa yang kurang disiplin saat mengikuti pelajaran pembelajaran matematika sehingga menjadi pembelajaran yang dianggap siswa sulit dan kurang menarik, (2) Siswa baru akan memberikan pendapatnya jika ditunjuk langsung oleh guru. Kalaupun ada siswa yang semangat untuk 
mengikuti pembelajaran, hanya terbatas pada saat mengerjakan latihan soal, sebagian siswa hanya mengandalkan pekerjaan temannya tanpa mau berusaha sendiri. Berdasarkan pada penelitian pendahulu yang telah dilakukan pada siswa kelas X SMA Al Azhar 3 Bandar Lampung menunjukan bahwa sebanyak 62 \% siswa belum tercapainya ketuntasan kriteria minimal (KKM) yaitu nilai 70. Dan sebanyak 38\% siswa sudah mencapai ketuntasan. Jadi dapat disimpulkan bahwa hasil belajar matematika siswa SMA Al Azhar 3 Bandar Lampung perlu ditingkatkan. Salah satu pendekatan yang dapat digunakan untuk mendukung pembelajaran matematika yang berorientasi pada siswa yaitu pendekatan problem posing. Problem Posing merupakan perumusan masalah yang menekankan pada pengalaman dan memformulasikan soal-soal. Siswa mampu menemukan konsep sendiri pada pengetahuannya Sehingga guru dapat mengetahui sejauh mana pemaham siswa Beberapa hasil penelitian menemukan bahwa pembelajaran dengan pendekatan problem posing memiliki dampak positif terhadap prestasi belajar siswa, antara lain pada penelitian saleh haji, menyebutkan bahawa pembelajaran dengan Pendekatan problem posing menunjukan hasil yang lebih baik dalam meningkatkan kemampuan pemecahan masalah matematika pada sekolah tingkat dasar [3], sedangkan pada Hasil penelitian Anita, problem posing merupakan salah stau bentuk kegiatan dalam pembeljaaran matematika yang dapat mengaktifkan, mengembangkan kemampuan berpikir mahasiswa dan menimbulkan sikap positif dalam pembelajaran matematika [4].

Pendekatan problem posing terfokus pada upaya peserta didik secara sengaja menemukan pengetahuan dan pengalaman-pengalaman baru dalam rangka memecahkan masalah yang lebih komplek. Oleh karena itu, problem posing dapat menjadi salah satu alternatif untuk mengembangkan berpikir matematis atau pola pikir matematis. 


\section{METODE PENELITIAN}

Penelitian ini adalah penelitian eksperimen. Populasi siswa kelas $\mathrm{X}$ Semester Genap SMA Al Azhar 3 Bandar Lampung,. Teknik Pengambilan sampel menggunakan Teknik cluster random sampling. Kelas yang menerapkan pendekatan problem posing sebagai kelas eksperimen, yaitu kelas X3. Kelas yang menerapkan pembelajaran konvensional sebagai kelas kontrol, yaitu kelas X 1. Analisis Data menggunakan uji statistik. Alat tes yang digunakan adalah sebanyak 10 soal essay sebagai alat ukurnya. Dengan memberikan skor penilaian sebagai berikut:

Tabel 1. Skor Penilaian

\begin{tabular}{lc}
\hline Kriteria & Skor Penilaian \\
\hline Untuk Jawaban Benar & $(10)$ \\
Untuk Jawaban setengah atau jawaban & $(5)$ \\
akhirnya salah tetapi proses deskripsi & \\
sudah benar & \\
Untuk Jawaban akhir benar tetapi tanpa & $(0)$ \\
langkah penyelsaian dalam pertanyaan & \\
yang membutuhkan deskripsi atau & $(0)$ \\
tanpa deskripsi & \\
Jawaban yang salah & \\
\hline engan demikian skor atau nilai tertinggi adalah 100 dan nilai
\end{tabular}
terendah adalah 0. Jadi nilai siswa akan berkisar 0-100.

Sistem penilaian yang akan digunakan :

$$
\left(N=\frac{\text { skor yang didapat }}{\text { skor maksimal }} \times 100\right)
$$




\section{HASIL DAN PEMBAHASAN}

Dari hasil penelitian menunjukkan hasil tes yang diperoleh dari pemberian tes di kelas eksperimen (menerapkan pendekatan problem posing) dan kelas kontrol (menerapkan pembelajaran konvensional ). Hasil tes kelas eksperimen dan kelas kontrol dapat dilihat pada Tabel 2 berikut.

Table 2. Rekapitulasi Hasil Tes Kelas Eksperimen dan Kontrol

\begin{tabular}{ccccc}
\hline Kelompok & $\begin{array}{c}\text { Jumlah } \\
\text { Siswa }\end{array}$ & $\begin{array}{c}\text { Skor } \\
\text { Tertinggi }\end{array}$ & $\begin{array}{c}\text { Skor } \\
\text { Terendah }\end{array}$ & $\begin{array}{c}\text { Nilai Rata- } \\
\text { Eksperimen }\end{array}$ \\
40 & 100 & 44 & 77,5 \\
Kontrol & 42 & 85 & 51 & 68,64 \\
\hline
\end{tabular}

Dari hasil tes matematika antara kelas eksperimen dan kelas kontrol ternyata dapat dibandingkan bahwa skor rata-rata kelas eksperimen adalah 77.5 dan kelas kontrol adalah 68,64. Selain itu jika kita melihat nilai tertinggi dari kelas eksperimen yaitu 100 dan nilai terendah adalah 44. Sedangkan kelas kontrol memiliki nilai tertinggi 85 dan nilai terendah 51. Hasil ini menunjukkan bahwa kelas eksperimen dengan Pendekatan Pembelajaran problem posing memiliki hasil tes yang cukup baik jika dibandingkan dengan pembelajaran pada kelas kontrol.

\section{Analisis data}

Setelah data penelitian diperoleh, selanjutnya data tersebut dianalisis. Analisis data juga dilakukan untuk memperkuat hasil hipotesis atau kesimpulan akhir. Data hasil uji kelompok eksperimen dan kelompok kontrol dianalisis dengan Uji Normalitas Data, Uji Homogenitas Varians dan Uji Hipotesis dengan menggunakan rumus statistik, sehingga didapat skor rata-rata hasil dari masing-masing kelompok. Jika data dianalisis dengan cara tidak terdistribusi maka dapat digunakan teknik statistik parametrik, sedangkan jika data tidak berdistribusi normal maka harus digunakan statistik non parametrik 


\section{Hipotenusa}

Journal of Research Mathematics Education VOL.3 NO.2 2020

[5]. Uji normalitas data untuk kelas eksperimen dapat dilihat pada tabel 3.

Tabel 3. Distribusi Frekuensi Kelas Eksperimen

\begin{tabular}{cccccc}
\hline Nilai & $\mathbf{f}_{\mathbf{i}}$ & $\boldsymbol{x}_{\mathbf{i}}$ & $\boldsymbol{x}_{\mathbf{i}}{ }^{2}$ & $\boldsymbol{f}_{\mathrm{i} \cdot} \boldsymbol{x}_{\mathbf{i}}$ & $\boldsymbol{f}_{\mathbf{i} \cdot \boldsymbol{x}_{\mathbf{i}}{ }^{2}}$ \\
\hline $54-61$ & 3 & 57,5 & 3306,25 & 172,5 & 9918,75 \\
$62-69$ & 6 & 65,5 & 4290,25 & 393 & 25741,5 \\
$70-77$ & 14 & 73,5 & 5402,25 & 1029 & 75631,5 \\
$78-85$ & 5 & 81,5 & 6642,25 & 407,5 & 33211,25 \\
$86-93$ & 9 & 89,5 & 8010,25 & 805,5 & 72092,25 \\
$94-101$ & 3 & 97,5 & 9506,25 & 292,5 & 28518,75 \\
Jumlah & $\sum \mathbf{4 0}$ & & & $\sum^{3100}$ & $\sum \mathbf{2 4 5 1 1 4}$ \\
\hline
\end{tabular}

\section{Sumber : Pengolahan Data}

Untuk menghitung frekuensi teoritis akan ditentukan terlebih dahulu :

1. Menentukan batas kelas $(x)$.

2. Menghitung $\mathrm{Z}$ untuk batas, dengan rumus :

$$
Z=\frac{x-\overline{x_{1}}}{S_{1}}
$$

3. Menghitung luas kelas interval dengan melihat tabel F.

4. Menghitung frekuensi yang diharapkan $\left(E_{i}\right)$ dengan mengalikan luas tiap kelas dengan banyaknya data yaitu $\left(E_{i}\right)=L_{i}, n$

Berdasarkan ketentuan tersebut, dapat diperoleh hasil yang tertera pada tabel berikut :

Tabel 4

\section{Daftar Distribusi Frekuensi yang Diharapkan dan Frekuensi Pengamatan Siswa pada Kelas Eksperimen [1]}

\begin{tabular}{cccccc}
\hline$\left(\boldsymbol{X}_{\boldsymbol{i}}\right)$ & $\left(\boldsymbol{Z}_{\boldsymbol{i}}\right)$ & $(\boldsymbol{Z})$ & $\left(\boldsymbol{L}_{\boldsymbol{i}}\right)$ & $\boldsymbol{E}_{\boldsymbol{i}}$ & $\boldsymbol{O}_{\boldsymbol{i}}$ \\
\hline 53,5 & $-2,15$ & 0,4842 & 0,0606 & 2,424 & 3 \\
61,5 & $-1,43$ & 0,4236 & & & 6,1594 \\
69,5 & $-0,72$ & 0,2642 & & &
\end{tabular}




\section{Hipotenusa}

Journal of Research Mathematics Education

\begin{tabular}{cccccc}
77,5 & 0 & 0,0000 & 0,2642 & 10,568 & 14 \\
85,5 & 0,72 & 0,2642 & 0,2642 & 10,568 & 5 \\
93,5 & 1,43 & 0,4236 & 0,1594 & 6,376 & 9 \\
\hline 1,5 & 2,15 & 0,4842 & 0,0606 & 2,424 & 3
\end{tabular}

$101,5 \quad 2,15 \quad 0,4842$

\section{Sumber : Pengolahan Data}

\section{Uji Normalitas Data Kelas Kontrol}

Berikut merupakan daftar nilai matematika kelas kontrol diperoleh sebagai berikut terdapat pada Tabel 5 :

Tabel 5 Daftar daftar nilai matematika kelas kontrol

\begin{tabular}{cccccc}
\hline Nilai & $\mathbf{f}_{\mathrm{i}}$ & $\boldsymbol{x}_{\mathrm{i}}$ & $\boldsymbol{x}_{\mathrm{i}}{ }^{2}$ & $\boldsymbol{f}_{\mathrm{i} \cdot \boldsymbol{x}_{\mathrm{i}}}$ & $\boldsymbol{f}_{\mathrm{i} \cdot \boldsymbol{x}_{\mathbf{i}}{ }^{2}}$ \\
\hline $51-56$ & 5 & 53,5 & 2862,25 & 262,5 & 14311,25 \\
$57-62$ & 5 & 59,5 & 3540,25 & 297,5 & 17701,25 \\
$63-68$ & 12 & 65,5 & 4290,25 & 786 & 51483 \\
$69-74$ & 8 & 71,5 & 5112,25 & 572 & 40890 \\
$75-80$ & 7 & 77,5 & 6006,25 & 542,5 & 42043,75 \\
$81-86$ & 5 & 83,5 & 6972,25 & 417,5 & 34861,25 \\
\hline Jumlah & $\sum \mathbf{4 2}$ & & & $\sum \mathbf{2 8 8 3}$ & $\sum \mathbf{2 0 1 2 9 0 , 5}$ \\
\hline
\end{tabular}

\section{Sumber : Pengolahan Data}

\section{Uji Homogenitas Varians}

Setelah perhitungan diperoleh $\mathrm{F}_{\text {hit }}<\mathrm{F}_{\text {tabel }}$ dengan taraf signifikan 5\% diperoleh 1,51<1, 69 dan dengan taraf signifikan 1\% diperoleh ,51< 2,11 sehingga dapat disimpulakan kedua data mempunyai varians yang homogen. 


\section{Hipotenusa}

Journal of Research Mathematics Education

VOL.3 NO.2 2020

\section{Pengujian Hipotesis}

\section{Uji Kesamaan Dua Rata-rata}

Untuk menguji hipotesis Ada pengaruh pengaruh penerapan pendekatan Problem Posing terhadap hasil belajar matematika pada siswa kelas X Semester Genap SMA Al Azhar 3 Bandar Lampung, Hypotesis nya sebagai berikut :

$H_{0}: \mu_{1}=\mu_{2}$ Tidak ada pengaruh penerapan pendekatan Problem Posing terhadap hasil belajar matematika pada siswa kelas X Semester Genap SMA Al Azhar 3 Bandar Lampung

$H_{a}: \mu_{1} \neq \mu_{2}$ Ada pengaruh pengaruh penerapan pendekatan Problem Posing terhadap hasil belajar matematika pada siswa kelas X Semester Genap SMA Al Azhar 3 Bandar Lampung

Berdasarkan hasil analisis diperoleh $t_{\text {hit }}=3,96$ dengan $\left(d k=n_{1}+n_{2}-2\right)$ dengan taraf signifikan $(\alpha) 5 \%$ dan $1 \%$ dengan kriteria Uji Terima $H_{0}$ jika $-t_{1-1 / 2 \pi}<t<t_{1-1 / 2 \pi}$, dimana $t_{1-1 / 2 \pi}$ didapat dari daftar distribusi $t$ dengan $\left(d k=n_{1}+n_{2}-2\right)$ dan peluang $(1-1 / 2 \alpha)$, sebaliknya $H_{0}$ ditolak. dari hasil perhitungan diatas terlihat bahwa baik pada taraf $5 \%$ maupun $1 \%$ ternyata $t_{\text {hit }}$ tidak berada dalam daerah penerimaan $H_{0}$, ini berarti ada pengaruh penerapan pendekatan problem posing terhadap hasil belajar matematika pada siswa kelas X Semester Genap SMA Al-Azhar 3 Bandar Lampung. Dari hasil penelitian yang sudah dilakukan, dapat diketahui bahwa untuk pengujian kesamaan dua rata-rata didapat $t_{\text {hit }}=3,96$. Kriteria uji yang digunakan adalah diterima $H_{0}$ jika $-t_{\left(1-\frac{1}{2} \alpha\right)(d k)}<t_{\text {hit }}<t_{\left(1-\frac{1}{2} \alpha\right)(d k)}$ dengan ( $\left.d k=n_{1}+n_{2}-2\right)$, sebaliknya $H_{0}$ ditolak. Dengan mengambil taraf $\alpha=0,05$ didapat 1,99 dan dengan mengambil taraf $\alpha=0,01$ didapat 2,65. Dapat dilihat bahwa $t_{\text {hit }}$ tidak ada dalam taraf penerimaan baik untuk taraf $\alpha=0,05$ maupun $\alpha=0,01$. Maka dari kedua kriteria uji tersebut berarti $t_{\text {hit }}$ tidak berada dalam daerah 
penerimaan $H_{0}$, sehingga $H_{0}$ ditolak yang artinya ada pengaruh penerapan pendekatan Problem Posing terhadap hasil belajar matematika siswa. Hal ini menunjukkan bahwa penggunaan pendekatan problem posing sangat berpengaruh terhadap hasil belajar matematika. Dengan demikian, akan lebih baik apabila siswa dibiasakan melakukan pembelajaran dengan pendekatan problem posing sesuai dengan materi yang sedang dipelajari.

\section{KESIMPULAN DAN SARAN}

Berdasarkan analisis data dan pengujian hipotesis yang telah dijelaskan oleh penulis, diperoleh kesimpulan sebagai berikut:

1. Ada Pengaruh penerapan pendekatan problem posing terhadap hasil belajar matematika siswa kelas X Semester Genap SMA Al Azhar 3 Bandar Lampung

2. Hasil belajar matematika rata-rata siswa yang menerapkan pendekatan problem posing lebih tinggi dari hasil belajar matematika rata-rata siswa yang menerapkan pembelajaran konvensional.

Melihat kesimpulan yang dijelaskan di atas, juga untuk meningkatkan pembelajaran hasil belajar siswa dan kualitas pendidikan terutama dalam pembelajaran matematika para penulis memberikan saran-saran berikut:

1. Untuk meningkatkan hasil belajar matematika siswa, guru harus dapat memotivasi siswa untuk merasa senang dalam belajar matematika dan belajar lebih menarik bagi siswa.

2. Matematika adalah ilmu yang abstrak untuk itu dalam proses pembelajaran matematika yang terkait dengan kehidupan siswa sesuai dengan tingkat perkembangan, karena untuk pelajaran matematika akan mudah diterima jika peristiwa dan contoh ada di sekitar siswa, untuk itu kita membutuhkan pendekatan model pembelajaran. 


\section{Hipotenusa}

Journal of Research Mathematics Education VOL.3 NO.2 2020

3. Hasil penelitian ini dapat digunakan sebagai bahan pertimbangan dalam pemilihan model pembelajaran sehingga pembelajaran menjadi lebih efektif.

Dengan demikian hasil dan kesimpulan dari penelitian ini dan beberapa saran yang dapat berguna dalam meningkatkan hasil belajar siswa, terutama di bidang studi matematika dengan menerapkan pendekatan problem posing.

\section{DAFTAR PUSTAKA}

[1] F. Lestari et al., "Cooperative Learning Application with the Method of Network Tree Concept Map: Based on Japanese Learning System Approach," Educ. J. Gift. Young Sci., vol. 7(1), pp. 15-32, 2019, doi: https://doi.org/10.17478/jegys.471466.

[2] J. Asterius and Pardjono, "PENGARUH PEMBELAJARAN PROBLEM POSING TERHADAP KEMAMPUAN BERPIKIR KRITIS DAN KOMUNIKASI MATEMATIS SISWA KELAS V SD," Prima Edukasia, vol. 4 (1), 2016.

[3] S. Haji, "Pendekatan Problem Posing Dalam Pembelajaran Matematika di Sekolah Dasar," Universitas Bengkulu, 2015.

[4] Anita, "Peningkatakan Kemampuan Menyelesaikan Masalah Matematika melalui Pendekatan Problem Posing Mahasiswa jelas IA SMP Khadijah Makasar," UNM, 2005.

[5] A. Saregar and W. Sunarno, "Eksperimen dan Demonstrasi Diskusi menggunakan Multimedia Interaktif ditinjau dari Sikap Ilmiah dan Kemampuan Verbal Siswa," Inkuiri, vol. 2(2), 2013. 